Article

\title{
Direct synthesis of nitrogen-doped mesoporous carbons for acetylene hydrochlorination
}

\author{
Yong Yang, Guojun Lan, Xiaolong Wang, Ying Li* \\ Institute of Industrial Catalysis, Zhejiang University of Technology, Hangzhou 310014, Zhejiang, China
}

\section{A R T I C L E I N F O}

Article history:

Received 5 March 2016

Accepted 8 May 2016

Published 5 August 2016

\section{Keywords:}

Acetylene

Hydrochlorination

Vinyl chloride

Mercury-free

$\mathrm{N}$-doped carbon

\begin{abstract}
A B S T R A C T
Nitrogen-doped ordered mesoporous carbon (N-OMC) catalysts were directly synthesized using SBA-15 as a hard template and sucrose as a carbon source. Urea, which was used as the nitrogen source, was carbonized with sucrose. A $3.6 \mathrm{wt} \%$ nitrogen doping of the carbon framework was achieved, with more than $70 \%$ of the nitrogen incorporated as quaternary nitrogen species. Only 0.2 wt $\%$ nitrogen doping, with only $32.7 \%$ quaternary nitrogen incorporation was obtained in an $\mathrm{N}-\mathrm{OMC}$ catalyst (N-OMC-T) prepared using a two-step post-synthesis method. The acetylene hydrochlorination activities of $\mathrm{N}-\mathrm{OMC}$ catalysts prepared via the one-step method were higher than that of the N-OMC-T catalyst because of the higher nitrogen loadings.
\end{abstract}

(C) 2016, Dalian Institute of Chemical Physics, Chinese Academy of Sciences. Published by Elsevier B.V. All rights reserved.

\section{Introduction}

Poly(vinyl chloride) (PVC) is one of the most widely used engineering plastics. It has a broad range of applications because of its advanced properties. PVC is manufactured from vinyl chloride monomer (VCM). About $41 \%$ of PVC is produced in China. In China, VCM is mainly produced by acetylene hydrochlorination using $\mathrm{HgCl}_{2}$ /activated carbon (AC) catalysts $[1,2]$. Mercury-based catalysts are toxic and cause environmental problems. Therefore it is imperative to develop non-mercury catalysts for acetylene hydrochlorination as alternatives to $\mathrm{HgCl}_{2} / \mathrm{AC}$ catalysts. Based on the previously reported correlations between the activities of various metal chloride catalysts and standard electrode potentials [3,4], several non-mercury catalysts for acetylene hydrochlorination have been investigated. Hutchings et al. [5,6] reported that gold-based catalysts were the best metal chloride catalysts for acetylene hydrochlorination, but such catalysts are easily deactivated via reduction of the active $\mathrm{Au}^{3+}$ species to metallic gold during the reaction $[5,6]$. Much effort has been made to elucidate the reaction and reduction mechanism of gold-based catalysts [7-10]. However, the commercialization of gold-based non-mercury catalysts is difficult because of the high price of gold. Catalysts based on other noble and non-precious metal catalysts such as Ru [11-13], Ag [2], Pt [14], Pd [15,16], Rh and Ir [7], and $\mathrm{Cu}[15,17]$ for acetylene hydrochlorination have also been investigated. Metal-based catalysts need to be further improved to prevent rapid deactivation and low acetylene conversions, and the development of catalysts that do not contain mercury or noble metals is important.

Recently, metal-free heterogeneous catalysts have attracted much attention and have proved to be versatile functional materials for heterogeneous catalysis of various reactions, including oxygen reduction reactions [18-20], biomass conversion

\footnotetext{
* Corresponding author. Tel: +86-571-88320766; Fax: +86-571-88320259; E-mail: liying@zjut.edu.cn This work was supported by the National Natural Science Foundation of China (20803064) and the Natural Science Foundation of Zhejiang Province (Y4090348). 
[21], and acetylene hydrochlorination [22-25]. Nitrogen-doped carbon materials, in particular, have been widely studied because of their surface chemistry and the electron-donating properties of nitrogen species. Nitrogen-doped carbon materials prepared using chemical vapor deposition, heat-treatment with nitrogen sources, or direct carbonization of nitrogen containing precursors has been proposed as catalysts for acetylene hydrochlorination. Li et al. [22] prepared an AC-based g- $\mathrm{C}_{3} \mathrm{~N}_{4}$ catalyst ( $\mathrm{g}-\mathrm{C}_{3} \mathrm{~N}_{4} / \mathrm{AC}$ ) using cyanamide as a nitrogen-containing precursor. The g- $\mathrm{C}_{3} \mathrm{~N}_{4} / \mathrm{AC}$ catalyst had a high surface area and nitrogen content, and significantly improved the conversion of acetylene to $76.52 \%$ at $180^{\circ} \mathrm{C}$ and a gas hourly space velocity (GHSV) of $50 \mathrm{~h}^{-1}$, showing that pyridinic nitrogen can provide active sites in $\mathrm{g}-\mathrm{C}_{3} \mathrm{~N}_{4} / \mathrm{AC}$. Zhou et al. [24] synthesized a nitrogen-doped carbon nanotube catalyst via chemical vapor deposition; the catalyst gave a turnover frequency (TOF) of $2.3 \times$ $10^{-3} \mathrm{~s}^{-1}$, suggesting that quaternary nitrogen species, rather than pyridinic or pyrrolic nitrogen, were the active sites. Bao's group [25] overcame disadvantages such as shaping difficulties and low mechanical strength by preparing a SiC-based nitrogen-doped carbon catalyst. They achieved an acetylene conversion of $80 \%$ in a $150 \mathrm{~h}$ test at $200{ }^{\circ} \mathrm{C}$ and $30 \mathrm{~h}^{-1}$. They found that the active sites were pyrrolic nitrogen species and that little acetylene was adsorbed on quaternary and pyridinic nitrogen. In a later study, Zhang et al. [26] found that the catalytic activity of nitrogen-doped AC catalysts in acetylene hydrochlorination depended strongly on the nitrogen species present, and the activity order was pyrrolic nitrogen $>$ graphitic nitrogen $>$ pyridinic nitrogen.

There have been few systematic studies of new preparation methods for nitrogen-doped carbons and the relationship between their active sites and catalytic activities. In this work, nitrogen-doped ordered mesoporous carbons (N-OMCs) were prepared, and the effects of the nitrogen species present on the catalytic performance in acetylene hydrochlorination were studied.

\section{Experimental}

\subsection{Materials}

Sucrose (Guangdong Guanghua Sci-Tech Co., Ltd., China), urea (Sinopharm Chemical Reagent Co., Ltd., China), tetramethoxysilane (98\%, Hangzhou Guibao Chemical Co., Ltd., China), HCl gas (99.999\%, Shuanglin Reagent Co., Ltd., China), and acetylene gas (99.9\%) were used. All materials were analytical grade and used without further purification.

\subsection{Preparation of $S B A-15$}

Mesoporous SBA-15 was synthesized using the method described by Zhao et al. [27].

\subsection{Preparation of N-OMCs via a one-step method}

In a typical procedure, taking a urea/sucrose mole ratio of 2.0 as an example, a precursor solution containing sucrose
(12.5 g), urea (4.45 g), and distilled water (43.0 mL) was prepared; $75 \%$ of the solution was infiltrated into SBA-15 silica ( $6.0 \mathrm{~g}$ ), followed by drying at $100{ }^{\circ} \mathrm{C}$ for $6 \mathrm{~h}$ and $160{ }^{\circ} \mathrm{C}$ for $6 \mathrm{~h}$. The infiltration and drying were repeated using the remaining $25 \%$ of the precursor solution. The composite was carbonized at $850{ }^{\circ} \mathrm{C}$ for $3 \mathrm{~h}$ under a nitrogen flow and then washed with sodium hydroxide solution at $70{ }^{\circ} \mathrm{C}$ to remove the silica template completely to give a template-free product. This sample is denoted by N-OMC-02.0, where 0 indicates a one-step process and 2.0 indicates a urea/sucrose ratio of 2.0 (Fig. 1).

The effects of the nitrogen content and type of nitrogen species were investigated by preparing N-OMC catalysts using urea/sucrose ratios of $0.5,1.0,2.0$, and 4.0 via the same procedure; the catalysts are denoted by $\mathrm{N}-\mathrm{OMC}-\mathrm{O} x$, where $x$ represents the urea/sucrose ratio.

\subsection{Preparation of N-OMCs via a two-step method}

For comparison, pure OMC was synthesized using the procedure described above, with SBA-15 as a hard template but without urea. N-OMC-T2.0, where T indicates a two-step process and 2.0 is the urea/sucrose ratio, was synthesized by carbonizing a composite prepared by pre-impregnating OMC with urea solution at $850^{\circ} \mathrm{C}$ for $3 \mathrm{~h}$ under a nitrogen flow (Fig. 1).

\subsection{Characterization}

Nitrogen sorption isotherms were recorded at $-196^{\circ} \mathrm{C}$ using a Quantachrome Autosorb-IQ instrument in static mode. Before the measurements, the samples were degassed at $200{ }^{\circ} \mathrm{C}$ for $10 \mathrm{~h}$. The carbon surface areas were calculated from the adsorption isotherms using the multipoint Brunauer-EmmettTeller method. The pore size distributions of the supports were determined from the desorption branches using the Barrett-Joyner-Halenda method.

High-resolution transmission electron microscopy (HRTEM) was performed using a Philips-FEI Tecnai G2 F30 S twin electron microscope, with a field-emission gun as the electron source, operated at $300 \mathrm{kV}$. The samples were mounted and ultrasonically dispersed in ethanol, and then a few droplets of the suspension were deposited on a copper grid coated with a holey carbon film, followed by drying under ambient conditions.

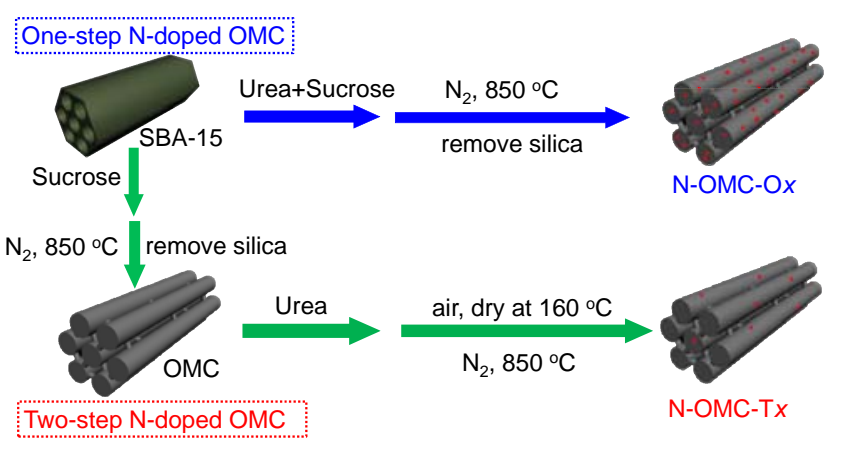

Fig. 1. Schematic diagram of synthesis of N-OMC-Ox and N-OMC-Tx from SBA-15 by the one-step and two-step methods. 
X-ray photoelectron spectroscopy (XPS) was performed with a Kratos AXIS Ultra DLD instrument using $300 \mathrm{~W}$ Al $K_{\alpha}$ radiation, with the $\mathrm{C} 1 \mathrm{~s}$ peak at $284.6 \mathrm{eV}$ as the internal standard. The carbon, hydrogen, nitrogen, and sulfur contents of the catalysts were determined using a MACRO cube elemental analyzer.

\subsection{Activity measurements}

The catalytic performance was investigated using a fix-bed glass reactor (i.d. $10 \mathrm{~mm}$ ). Acetylene was passed through sodium hypochlorite solution to remove trace impurities, and $\mathrm{HCl}$ gas was dried using $5 \mathrm{~A}$ molecular sieves. Acetylene $(2.42$ $\mathrm{mL} / \mathrm{min}$ ) and $\mathrm{HCl}(2.95 \mathrm{~mL} / \mathrm{min})$ were introduced into a heated reactor containing the catalyst $(3.0 \mathrm{~mL})$ through a mixing vessel with calibrated mass flow controllers, giving an acetylene gas $/ \mathrm{HCl}$ mixture pressure of $0.1 \mathrm{MPa}$, feed volume ratio $V_{\mathrm{HCl}} / V_{\mathrm{C} 2 \mathrm{H} 2}=1.1$, and GHSV $50 \mathrm{~h}^{-1}$ at $180{ }^{\circ} \mathrm{C}$. The microreactor was purged with nitrogen before the reaction to remove water and air. The reactor effluent was passed through an absorption bottle containing sodium hydroxide solution to remove unreacted hydrogen chloride. The gas mixture was analyzed using a gas chromatography (GC-1690F).

\section{Results and discussion}

\subsection{N-OMC and OMC structures}

The textural properties and nitrogen contents of the catalysts were determined using nitrogen adsorption-desorption methods and elemental analysis; the results are summarized in Table 1.

The isotherms (Fig. 2) of OMC, N-OMC-T2.0, and N-OMC-Ox are type $\mathrm{V}$, which is the typical adsorption isotherm for $\mathrm{OMC}$ materials with well-ordered mesoporous structures. All the isotherms show a sharp step characteristic of capillary condensation of nitrogen within uniform mesopores at high relative pressures $\left(p / p_{0}>0.35\right)$; the $p / p_{0}$, at which the inflection point is observed, is related to the mesopore diameter. The specific surface area of OMC is $1271 \mathrm{~m}^{2} / \mathrm{g}$, and the pore size is around $4.2 \mathrm{~nm}$, showing good replication of the template. The specific surface area of N-OMC-T2.0 is $952 \mathrm{~m}^{2} / \mathrm{g}$, and the pore size is $3.8 \mathrm{~nm}$. The pore size distributions of all the samples are narrow, suggesting predominantly uniform mesopores; this indicates that the urea addition method did not strongly affect the pore structure during carbonization. The surface areas and pore structures of the N-OMC-Ox samples are similar to those

Table 1

Textural properties and elemental analyses of OMC, N-OMC-T2.0, and N-OMC-Ox.

\begin{tabular}{|c|c|c|c|c|c|c|c|c|}
\hline \multirow{2}{*}{ Sample } & \multirow{2}{*}{$\begin{array}{l}\text { Urea/sucrose } \\
(\mathrm{mol} / \mathrm{mol})\end{array}$} & \multirow{2}{*}{$\begin{array}{l}\text { Surface area } \\
\left(\mathrm{m}^{2} / \mathrm{g}\right)\end{array}$} & \multirow{2}{*}{$\begin{array}{l}\text { Pore volume } \\
\left(\mathrm{cm}^{3} / \mathrm{g}\right)\end{array}$} & \multirow{2}{*}{$\begin{array}{c}D^{\mathrm{a}} \\
(\mathrm{nm})\end{array}$} & \multicolumn{4}{|c|}{ Elemental content (wt $\%$ ) } \\
\hline & & & & & $\mathrm{N}$ & $\mathrm{C}$ & $\mathrm{H}$ & 0 \\
\hline $\mathrm{OMC}$ & - & 1271 & 1.10 & 4.2 & - & 71.8 & 2.6 & 25.4 \\
\hline N-OMC-T2.0 & 2.0 & 952 & 1.00 & 3.8 & 0.2 & 83.0 & 1.3 & 15.2 \\
\hline N-OMC-00.5 & 0.5 & 607 & 0.69 & 3.8 & 2.7 & 65.1 & 2.4 & 29.6 \\
\hline N-OMC-01.0 & 1.0 & 656 & 0.73 & 3.8 & 3.1 & 72.3 & 2.3 & 22.1 \\
\hline N-OMC-02.0 & 2.0 & 613 & 0.71 & 3.8 & 3.4 & 72.6 & 2.0 & 21.8 \\
\hline N-OMC-04.0 & 4.0 & 337 & 0.58 & 4.3 & 3.6 & 58.9 & 2.4 & 35.0 \\
\hline
\end{tabular}

a Calculated from the desorption branch of isotherm according to the Barrett-Joyner-Halen (BJH) method.
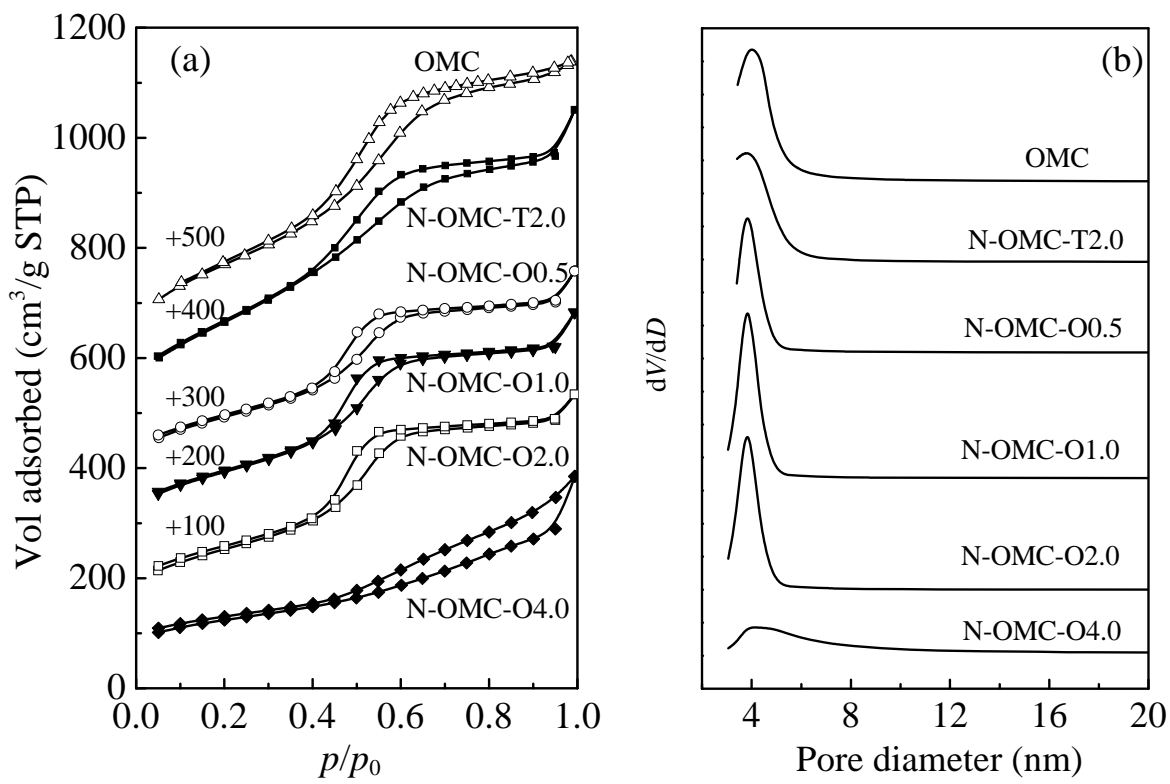

Fig. 2. Nitrogen adsorption-desorption isotherms (a) and pore size distributions (b) of OMC, N-OMC-T2.0 and N-OMC-Ox. 


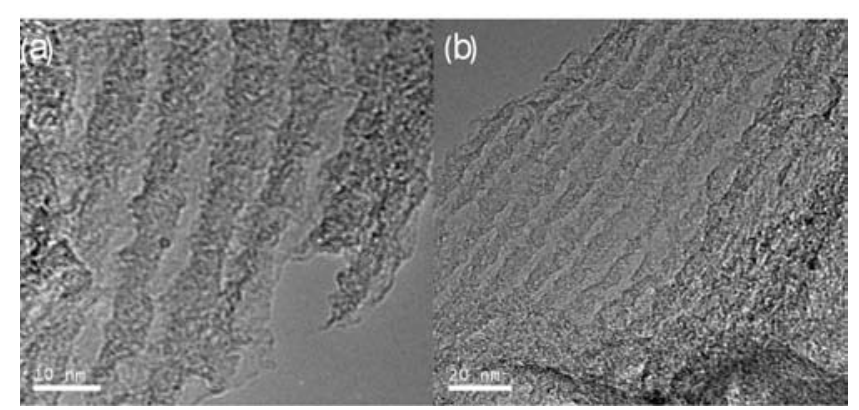

Fig. 3. TEM images of N-OMC-O2.0 (a) and N-OMC-T2.0 (b).

of pure OMC when the urea/sucrose ratio is less than 2.0 (urea/sucrose $=0.5,1.0$, and 2.0). However, for N-OMC-04.0, the surface area decreases to $337 \mathrm{~m}^{2} / \mathrm{g}$, indicating collapse of the ordered mesoporous structure. This is confirmed by the nitrogen sorption isotherms. The pore structures of the samples were examined using HRTEM. The images (Fig. 3) clearly show that N-OMC-02.0 and N-OMC-T2.0 have similar mesoporous structures consisting of well-ordered hexagonal mesopore arrays.

Elemental analysis was performed to determine the nitrogen contents of $\mathrm{N}-\mathrm{OMC}-\mathrm{O} x$ and $\mathrm{N}-\mathrm{OMC}-\mathrm{T} 2.0$; the results are shown in Table 1. The nitrogen content of N-OMC-Ox is much higher than that of N-OMC-T2.0. This may be because of strong linkages between urea and sucrose in the pre-carbonization and carbonization processes in the direct synthesis method. However, N-OMC-T2.0, prepared by carbonizing a composite synthesized by pre-impregnation of OMC with a urea solution, only has weakly physisorbed nitrogen impurities on its surface, therefore the nitrogen content is only $0.2 \mathrm{wt} \%$. The nitrogen content increases gradually from $2.7 \mathrm{wt} \%$ for N-OMC-00.5 to $3.6 \mathrm{wt} \%$ for N-OMC-04.0 when urea and sucrose are consecutively added. The oxygen content was calculated by subtracting the nitrogen, carbon, hydrogen, and sulfur contents, based on the assumption that there are no impurities in the samples and

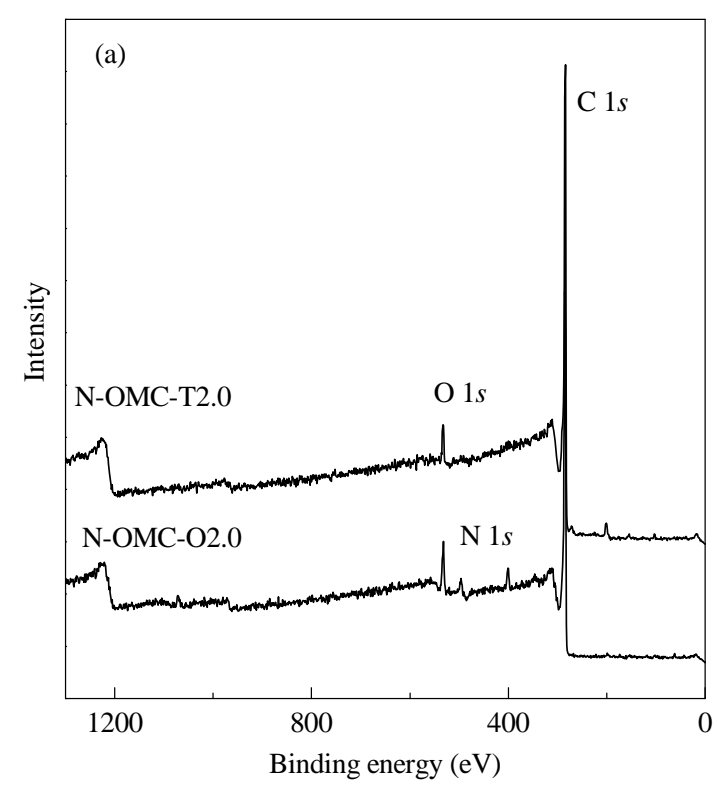

the total of the contents of these five elements represents $100 \%$. The data in Table 1 show that the oxygen content is about $25 \%-35 \%$. The oxygen content cannot be directly determined by elemental analysis; therefore, these data are not accurate.

The samples were characterized using temperature-programed desorption in argon (Ar-TPD). The results (figure not shown) show that the $\mathrm{N}-\mathrm{OMC}-\mathrm{O} x$ samples have similar profiles for $\mathrm{CO}$ and $\mathrm{CO}_{2}$, indicating that the types and contents of oxygen functional groups exposed on their surfaces are similar. The profiles for N-OMC-T2.0 show significantly lower amounts of $\mathrm{CO}$ and $\mathrm{CO}_{2}$, possibly because the surface oxygen groups were reconstructed after urea loading and thermal treatment at 850 ${ }^{\circ} \mathrm{C}$. No nitrogen-containing species such as $\mathrm{NO}, \mathrm{N}_{2}$, and $\mathrm{NH}_{3}$ were detected in the gas released during Ar-TPD; this shows that the nitrogen species cannot be desorbed below $850{ }^{\circ} \mathrm{C}$ or the nitrogen content is too low to be detected.

\subsection{Identification of nitrogen states using XPS}

The nitrogen species in the N-OMC samples were identified using XPS. Fig. 4(a) shows the wide $\mathrm{N} 1 \mathrm{~s}$ regions for $\mathrm{N}-\mathrm{OMC}-\mathrm{T} 2.0$ and N-OMC-02.0; the figure also shows that $\mathrm{N}-\mathrm{OMC}-\mathrm{O} 2.0$ and N-OMC-T2.0 contain only oxygen, nitrogen, and carbon. Fig. 4(b) shows the $\mathrm{N} 1 \mathrm{~s}$ core level peaks for N-OMC-02.0 and N-OMC-T2.0. No peak is observed for OMC. N-OMC-02.0 and N-OMC-T2.0 give three peaks at binding energies of 398.3, 400.0, and $401.1 \mathrm{eV}$. These peaks can be assigned to pyridinic $(398.3 \pm 0.2 \mathrm{eV})$, pyrrolic $(400.0 \pm 0.2 \mathrm{eV})$, and quaternary $(401.1 \pm 0.2 \mathrm{eV}) \mathrm{N}$ species, respectively [28,29]. It should be noted that the proportion of quaternary nitrogen in N-OMC-02.0 is higher than that in N-OMC-T2.0 (Table 2). The nitrogen species in $\mathrm{N}-\mathrm{OMC}-02.0$, which was prepared via a one-step method, were introduced by in situ carbonization of urea and sucrose and are probably more easily doped into the carbon framework. The data in Table 2 show that the quater-

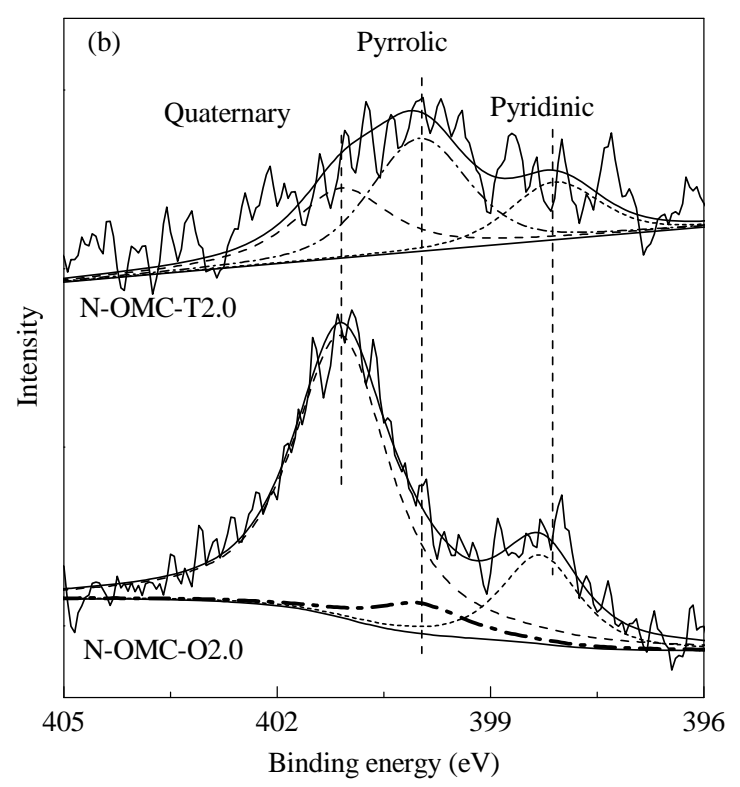

Fig. 4. Wide (a) and high-resolution (b) N 1s XPS profiles of N-OMC-T2.0 and N-OMC-O2.0. 
Table 2

Ratios of quaternary, pyrrolic, and pyridinic $\mathrm{N}$ to total $\mathrm{N}$ amount evaluated by peak separation analyses of $\mathrm{N} 1 s$ core level peaks.

\begin{tabular}{lcccc}
\hline \multirow{2}{*}{ Sample } & \multicolumn{3}{c}{ Relative content (\%) } & $w(\mathrm{~N})$ \\
\cline { 2 - 4 } & Quaternary N & Pyrrolic N & Pyridinic N & $/ \%$ \\
\hline N-OMC-T2.0 & 32.7 & 45.5 & 21.8 & 0.4 \\
N-OMC-00.5 & 77.9 & 2.6 & 19.5 & 3.5 \\
N-OMC-01.0 & 76.5 & 3.8 & 19.7 & 3.4 \\
N-OMC-02.0 & 74.3 & 8.0 & 17.7 & 3.9 \\
N-OMC-04.0 & 61.5 & 16.7 & 21.8 & 5.4 \\
\hline
\end{tabular}

nary nitrogen content decreases slightly with increasing urea/sucrose ratio, especially in the case of N-OMC-04.0, for which the quaternary nitrogen content deceases to $61.5 \%$ from $77.69 \%$. This could be because there is a maximum quaternary nitrogen content for samples prepared using the present method. For N-OMC-T2.0, prepared via a post-synthesis method, the quaternary nitrogen content, i.e., $32.7 \%$, is much lower than those of the N-OMC-Ox samples. The dominant species are pyridinic and pyrrolic nitrogen. The one-step method is therefore more suitable for obtaining a framework doped with quaternary nitrogen species.

The surface nitrogen loadings of various samples, determined using XPS, are shown in Table 2. For the N-OMC-O $x$ and N-OMC-T2.0 catalysts, the surface nitrogen loadings obtained using XPS are higher than the nitrogen contents obtained using elemental analysis, indicating that the surface nitrogen concentrations are higher than those of the bulk. For N-OMC-04.0, the nitrogen loading determined using XPS is 5.4\%, whereas elemental analysis gives a nitrogen loading of 3.6\%. The N 1s XPS spectra (figure not shown) show that the pyridinic and pyrrolic nitrogen contents of this sample are higher than those of the other samples. This may indicate that these two nitrogen species are more easily exposed on the surfaces of the carbon materials.

\subsection{Catalytic performance of various $\mathrm{N}-\mathrm{OMC}$ samples}

The catalytic performance of N-OMC-02.0, N-OMC-T2.0, and $\mathrm{OMC}$ in acetylene hydrochlorination is shown in Fig. 5. The acetylene conversions of N-OMC-02.0, N-OMC-T2.0, and OMC

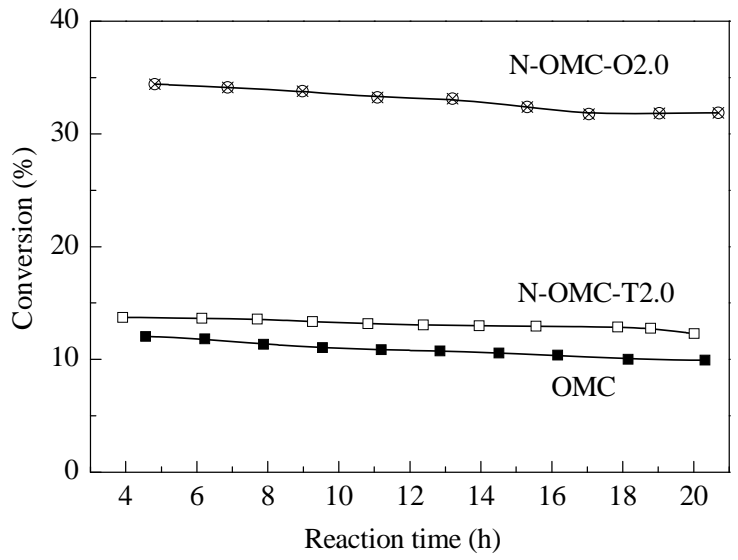

Fig. 5. Acetylene conversions for $\mathrm{OMC}, \mathrm{N}-\mathrm{OMC}-\mathrm{T} 2.0$, and N-OMC-2.0 at reaction temperature $180^{\circ} \mathrm{C}$, acetylene GHSV $50 \mathrm{~h}^{-1}$, pressure (acetylene plus $\mathrm{HCl}$ ) $0.1 \mathrm{MPa}$, and feed volume ratio $V_{\mathrm{HCl}} / V_{\mathrm{C} 2 \mathrm{H} 2}=1.1$.

were $33.5 \%, 12.5 \%$, and $10.0 \%$, respectively. The activities of N-OMC-02.0 and N-OMC-T2.0 are better than that of OMC, and N-OMC-02.0 has a higher activity than N-OMC-T2.0. The VCM selectivities of all the catalysts are above 99\% (not shown).

The catalytic performance of the N-OMC catalysts was further investigated using $\mathrm{N}-\mathrm{OMC}-\mathrm{O} x$ samples with various urea/sucrose ratios; the results are shown in Fig. 6(a). The figure shows that the acetylene conversion increases from $19.5 \%$ to $33.5 \%$ as the urea/sucrose increases from 0.5 to 2.0 , and reaches a maximum at a ratio of 2.0. The acetylene conversion starts to decrease when the urea/sucrose ratio reaches 4.0. This may be because the pore structure collapses when there is an excessive amount of urea, as shown by the surface area and pore distribution results.

The intrinsic activities of the N-OMC-O $x$ were determined by calculating the TOF values based on acetylene conversions at $10 \mathrm{~h}$ and the total nitrogen loadings. OMC also contributed to acetylene conversion, but quantification of the active sites in OMC is difficult; therefore, the conversion of OMC was subtracted from the total conversions of the N-OMC series to calculate the TOFs based on the nitrogen loadings. The TOF values for N-OMC-Ox and N-OMC-T2.0 are shown in Fig. 6(b). For the
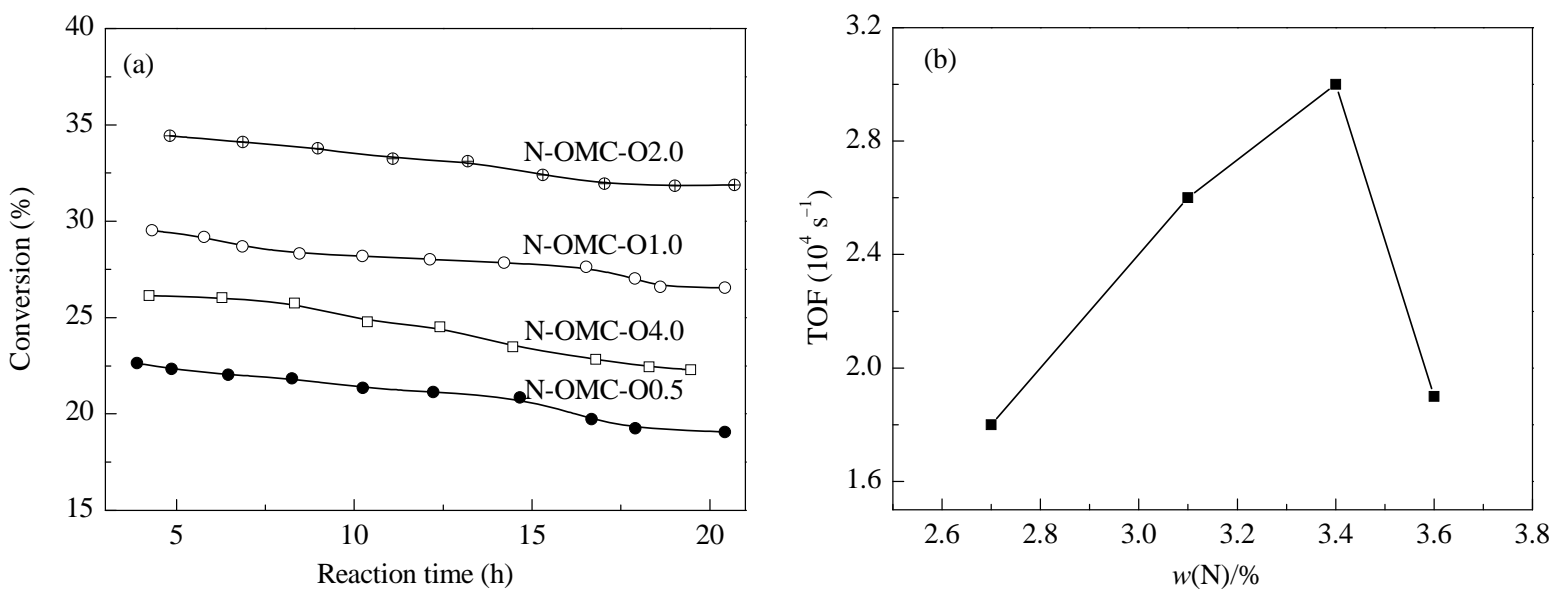

Fig. 6. Catalytic performance (a) and TOF values (b) of N-OMC-Ox. 
$\mathrm{N}-\mathrm{OMC}-\mathrm{O} x$ catalysts, the intrinsic activity increases with increasing nitrogen content from 2.7 to $3.4 \mathrm{wt} \%$, and reaches a maximum value at $3.4 \mathrm{wt} \%$, for $\mathrm{N}-\mathrm{OMC}-02.0$. This shows that nitrogen species must be the active sites for acetylene conversion, and that there is a positive correlation between acetylene conversion and nitrogen content. However, the TOF value for $\mathrm{N}-\mathrm{OMC}-04.0$ is low, although this sample has a nitrogen loading of $3.6 \mathrm{wt} \%$. This could be because of the low surface area of this sample. This indicates that the activity is affected by the pore structure of the N-OMC catalyst. The nitrogen-modified carbon nanotube catalyst synthesized by Zhou et al. [24] gave a TOF value of $2.3 \times 10^{-3} \mathrm{~s}^{-1}$ in acetylene hydrochlorination. This value was calculated based on the quaternary nitrogen atoms; the quaternary nitrogen content of the catalyst was lower than $2 \%$. There is no consensus regarding a positive relationship between activity and specific nitrogen species, and quaternary, pyrrolic, and pyridinic nitrogen are all considered to be active sites in acetylene hydrochlorination. It is therefore more appropriate to calculate TOF values based on the total nitrogen content. The TOF value of the N-OMC-02.0 catalyst calculated on the basis of the total nitrogen content is $3.0 \times 10^{-4} \mathrm{~s}^{-1}$; the activity level is similar.

\section{Conclusions}

We have developed a direct and facile method for the synthesis of N-OMC-Ox. Urea, which was used as a nitrogen source, was carbonized with sucrose; $3.6 \mathrm{wt} \%$ nitrogen doping of the carbon framework was achieved, with more than $70 \%$ of the nitrogen in the form of quaternary nitrogen species. Only 0.2 wt $\%$ nitrogen doping, with $32.7 \%$ quaternary nitrogen was achieved for N-OMC-T prepared via a post-synthesis method. The activities of the N-OMC-O catalysts prepared via a one-step method in acetylene hydrochlorination were higher than that of the N-OMC-T catalyst because of the higher nitrogen load- ings. The results of this study provide guidance for controlled synthesis to give materials containing a single type or one predominant type of nitrogen species to enable elucidation of the catalytic roles of different nitrogen sites in acetylene hydrochlorination. In further studies, efforts will be focused on the controlled synthesis of nitrogen-doped carbon materials with specific nitrogen species and higher nitrogen contents.

\section{References}

[1] J. L. Bing, C. Z. Li, Polyvinyl Chloride, 2011, 39(5), 1-8.

[2] B. Nkosi, N. J. Coville, G. J. Hutchings, Appl. Catal., 1988, 43, 33-39.

[3] D. M. Smith, P. M. Walsh, T. L. Slager, J. Catal., 1968, 11, 113-130.

[4] K. Shinoda, Chem. Lett., 1975, 219-220.

[5] G. J. Hutchings, R. Joffe, Appl. Catal., 1986, 20, 215-218.

[6] G. J. Hutchings, Catal. Today, 2002, 72, 11-19.

[7] B. Nkosi, N. J. Coville, G. J. Hutchings, M. D. Adams, J. Friedl, F. E. Wagner, J. Catal., 1991, 128, 366-399.

[8] M. Conte, A. F. Carley, C. Heirene, D. J. Willock, P. Johnston, A. A. Herzing, C. J. Kiely, G. J. Hutchings, J. Catal., 2007, 250, 231-239.

[9] J. L. Zhang, Z. He, W. Li, Y. Han, RSC Adv., 2012, 2, 4814-4821.

[10] Y. Wang, M. Y. Zhu, L. H. Kang, B. Dai, RSC Adv., 2014, 4, 38466-38493.

[11] M. Y. Zhu, L. H. Kang, Y. Su, S. Z. Zhang, B. Dai, Can. J. Chem., 2013, $91,120-125$.

[12] J. L. Zhang, W. Sheng, C. L. Guo, W. Li, RSC Adv., 2013, 3, 21062-21068.

[13] G. B. Li, W. Li, H. Y. Zhang, Y. F. Pu, M. X. Sun, J. L. Zhang, RSC Adv., 2015, 5, 9002-9008.

[14] S. A. Mitchenko, T. V. Krasnyakova, R. S. Mitchenko, A. N. Korduban, J. Mol. Catal. A, 2007, 275, 101-108.

[15] S. J. Wang, B. X. Shen, Q. L. Song, Catal. Lett., 2010, 134, 102-109.

[16] M. Conte, A. F. Carley, G. Attard, A. A. Herzing, C. J. Kiely, G. J. Hutchings, J. Catal., 2008, 257, 190-198.

[17] K. Zhou, J. K. Si, J. C. Jia, J. Q. Huang, J. Zhou, G. H. Luo, F. Wei, RSC Adv., 2014, 4, 7766-7769.

[18] M. Sevilla, L. H. Yu, T. P. Fellinger, A. B. Fuertes, M. M. Titirici, RSC

\section{Graphical Abstract}

Chin. J. Catal., 2016, 37: 1242-1248 doi: 10.1016/S1872-2067(16)62459-2

\section{Direct synthesis of nitrogen-doped mesoporous carbons for acetylene hydrochlorination}

Yong Yang, Guojun Lan, Xiaolong Wang, Ying Li*

Zhejiang University of Technology

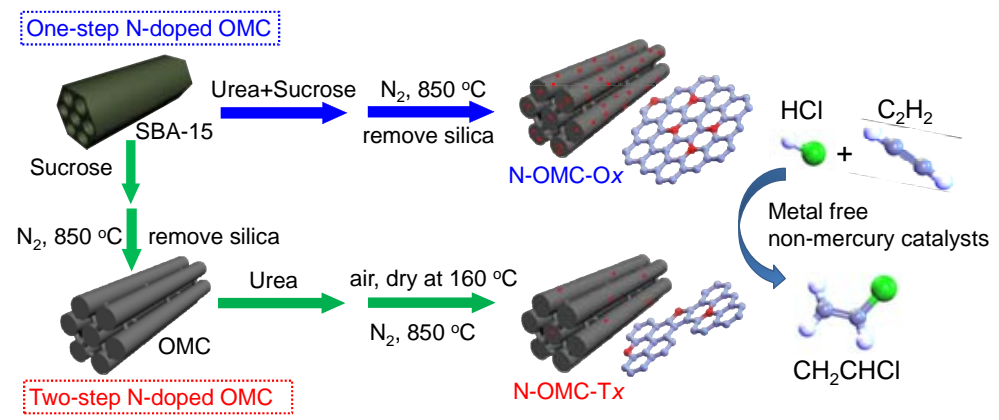

A direct method was developed for the synthesis of nitrogen-doped ordered mesoporous carbons (N-OMCs) in which nitrogen species can be introduced into the carbon framework with quaternary nitrogen as the dominant species. These catalysts show high activities in acetylene hydrochlorination. 
Adv., 2013, 3, 9904-9910.

[19] J. Lu, X. J. Bo, H. Wang, L. P. Guo, Electrochim Acta, 2013, 108, $10-16$.

[20] Y. Zheng, Y. Jiao, L. Ge, M. Jaroniec, S. Z. Qiao, Angew. Chem. Int. Ed., 2013, 52, 3110-3116.

[21] J. P. Tessonnier, A. Villa, O. Majoulet, D. S. Su, R. Schlogl, Angew. Chem. Int. Ed., 2009, 48, 6543-6546.

[22] X. Y. Li, Y. Wang, L. H. Kang, M. Y. Zhu, B. Dai, J. Catal., 2014, 311, 288-294.

[23] X. G. Wang, B. Dai, Y. Wang, F. Yu, ChemCatChem, 2014, 6, 2339-2344.
[24] K. Zhou, B. Li, Q. Zhang, J. Q. Huang, G. L. Tian, J. C. Jia, M. Q. Zhao, G. H. Luo, D. S. Su, F. Wei, ChemSusChem, 2014, 7, 723-728.

[25] X. Y. Li, X. L. Pan, L. Yu, P. J. Ren, X. Wu, L. T. Sun, F. Jiao, X. H. Bao, Nat. Commun., 2014, 5, 1-7.

[26] C. L. Zhang, L. H. Kang, M. Y. Zhu, B. Dai, RSC Adv., 2015, 5, 7461-7468.

[27] D. Y. Zhao, J. Y. Sun, Q. Z. Li, G. D. Stucky, Chem. Mater., 2000, 12, 275-279.

[28] R. J. J. Jansen, H. Van Bekkum, Carbon, 1995, 33, 1021-1027.

[29] J. R. Pels, F. Kapteijn, J. A. Moulijn, Q. Zhu, K. M. Thomas, Carbon, 1995, 33, 1641-1653.

\title{
原位掺杂法制备氮掺杂中孔炭及乙炔氢氯化反应性能
}

\author{
杨勇, 蓝国钧, 王小龙, 李 瑛* \\ 浙江工业大学工业催化研究所, 浙江杭州 310014
}

摘要: 聚氯乙烯 (PVC) 是世界五大工程塑料之一, 在工业、农业、建筑、电力及通信等领域有着非常广泛的应用. 氯乙烯 (VCM) 作为合成 PVC 的单体, 其生产工艺以源于煤化工路线的乙炔氢氯化法工艺为主, 但是该工艺目前采用的是氯化永 催化剂, 存在较为严重的环境污染问题. 开发新型无录催化剂成为电石法生产 VCM 亟待解决的问题. 氮掺杂炭基非金属 催化剂成本低廉, 制备简单, 在诸多反应中展现了较好的性能, 成为近几年多相催化领域的一个研究热点, 在乙炔氢氯化反 应中也具有较好的活性, 但是对活性中心的鉴别及制备方法的研究还有待深入.

本文报道了一种一步原位尿素掺杂氮的中孔炭的制备方法, 采用氮气吸附-脱附、高分辨透射电子显微镜、元素分析和 $\mathrm{X}$ 射线光电子能谱(XPS)等表征手段研究了氮掺杂中孔炭的结构、氮含量及存在形式, 并与两步尿素改性方法做了对比, 探 究了氮掺杂形式与中孔炭乙炔氢氯化反应性能之间的关系, 同时考察了尿素用量对氮掺杂中孔炭的氮含量和存在形式的 影响. 元素分析结果表明, 原位合成法能有效地将氮掺杂进骨架中, 随着制备过程中尿素用量增加, 得到的氮掺杂中孔炭 中的氮含量增加, 可达 $3.6 \mathrm{wt} \%$. 后处理法的掺氮效果较差, 材料氮含量仅为 $0.2 \mathrm{wt} \%$. XPS 测试进一步表明, 一步法原位 法可以得到石墨型氮占据主导地位的氮掺杂中孔炭, 石墨型氮约占 $70 \%$ 左右, 后处理制备的氮掺杂中孔炭中石墨氮、吡啶 氮和吡咯氮三种形式含量相差不大.

对不同方法合成的氮掺杂介孔炭的乙炔氢氯化反应催化性能进行了评价, 结果显示, 无论是原位合成还是后处理制备 的氮掺杂中孔炭, 其活性均比中孔炭得到一定提升. 氮的引入能有效提高材料的乙炔氢氯化反应性能. 原位合成法制备的 氮掺杂中孔炭在乙炔氢氯化反应中的催化性能远高于后处理法. 对于原位合成的氮掺杂中孔炭, 在一定范围内, 随着氮含 量的增加, 催化活性提高, 但当尿素用量过高时, 虽然氮含量增加, 催化活性却有所下降, 这归因于孔结构坍塌和比表面积 下降.

关键词: 乙炔; 氢氯化; 氯乙烯; 无录; 氮掺杂炭

收稿日期: 2016-03-05. 接受日期: 2016-05-08. 出版日期: 2016-08-05.

*通讯联系人.电话: (0571)88320766; 传真: (0571)88320259; 电子信箱: liying@zjut.edu.cn

基金来源：国家自然科学基金(20803064); 浙江省自然科学基金(Y4090348).

本文的英文电子版由Elsevier出版社在ScienceDirect上出版(http://www.sciencedirect.com/science/journal/18722067). 